\title{
Factors relating to visual acuity in children who have been treated for convergent squint
}

\author{
R M Ingram, C Walker, B Billingham, J Lucas, S Dally
}

\begin{abstract}
Retrospective analysis of a selected sample of children who presented with convergent squint has shown that abnormal meridional hypermetropia (3.5 D or more) at age 1 was the principal factor associated with severe amblyopia (6/24 or less) remaining after conventional treatment. Neither the reported age of onset nor delay in presentation influenced the final visual outcome.
\end{abstract}

It is widely believed that early onset of squint and/or delay in starting treatment have an adverse influence on amblyopia. Evidence for this is presented in Tables 3, 4, and 5 of Worth's book. ${ }^{1}$ They present the final visual results 'with optical correction and after all possible means have been used to remove any acquired amblyopia'. The only attempt to confirm this appears to be that of Costenbader et al. ${ }^{2}$ Like Worth they recognised that records of the age of onset of squint may be unreliable, but their conclusion was different: 'while the average age of onset may not be significant, the average duration of the squint before treatment is most significant in the production of amblyopia'.

This difference of opinion should be resolved, particularly as infantile ametropia ${ }^{3}$ has recently been identified as another factor possibly relevant to the incidence and severity of amblyopia. The present study assesses the association between these three factors and the severity of amblyopia in a group of treated children. They were selected on the basis that they were living in a particular area at age 1 year and refracted at that age. In carrying out the study we recognised that there were certain

TABLE I Age of onset

\begin{tabular}{llllllllll}
\hline \multirow{2}{*}{$\begin{array}{l}\text { Hypermetropia } \\
\text { at I year }\end{array}$} & \multicolumn{7}{l}{ Age of onset in months } \\
\cline { 2 - 9 } & $0-11$ & $12-23$ & $24-35$ & $36-47$ & $48-59$ & $60+$ & $?$ \\
\hline $3 \cdot 5+$ & $6 / 18$ or better & 2 & 2 & 3 & 5 & 1 & 4 & 5 \\
& $6 / 24$ or worse & 1 & 2 & 1 & 2 & - & - & 6 \\
\hline$<3 \cdot 5$ & $6 / 18$ or better & 4 & 8 & 8 & 5 & 5 & 5 & 17 \\
& $6 / 24$ or worse & 2 & - & - & 2 & - & - & - \\
\hline
\end{tabular}

Kettering District General Hospital, Rothwell Road, Kettering, Northants NN168UZ

$R$ M Ingram

C Walker

B Billingham

J Lucas

S Dally

Correspondence to:

Dr R M Ingram.

Accepted for publication 6 July 1989. unavoidable difficulties, namely, that the reported age of onset may be inaccurate, and sometimes not available; and compliance with treatment was difficult to assess.

\section{Patients and methods}

One hundred and sixty one children (approximately $4 \cdot 3 \%$ of the population) born between January 1974 and December 1978 and who were resident in and around the town of Kettering at age 1 year have presented to us with convergent
TABLE II Duration of squint

\begin{tabular}{llrrrrrr}
\hline \multirow{2}{*}{$\begin{array}{l}\text { Hypermetropia } \\
\text { at 1 year }\end{array}$} & \multicolumn{6}{c}{$\begin{array}{l}\text { Duration of squint in months before } \\
\text { treatment }\end{array}$} \\
\cline { 2 - 7 } & & $0-2$ & $3-4$ & $5-6$ & $7+$ & $?$ \\
\hline $3 \cdot 5+$ & $6 / 18$ or better & 8 & 6 & 1 & 2 & 5 \\
& $6 / 24$ or worse & 3 & 2 & - & 1 & 6 \\
\hline$<3 \cdot 5$ & $6 / 18$ or better & 16 & 11 & 4 & 4 & 17 \\
& $6 / 24$ or worse & 1 & - & 1 & 2 & - \\
\hline
\end{tabular}

squint. This report concerns 90 of these, who were refracted at 1 year, and did not have any of the following conditions: uniocular congenital cataract, colobomata, congenital nystagmus, or Down's syndrome.

Those children born between 1974 and 1977 were refracted after cycloplegia with atropine $1 \%$ at age 1 year, ${ }^{4}$ and those born in 1978 were refracted after cycloplegia with cyclopentolate $1 \%$ at age 1 year. To increase the number of children available for statistical analysis these two groups have been combined. Allowance has been made for the observation ${ }^{5}$ that retinoscopy after atropine cycloplegia shows approximately $0.5 \mathrm{D}$ more hypermetropia than after cycloplegia with cyclopentolate $1 \%$. In the following tables the figure for the cyclopentolate equivalent is quoted. 3.5 or more D or hypermetropia in the most hypermetropic meridian of each pair of eyes (meridional hypermetropia) has been recorded as abnormal hypermetropia. All the $\mathbf{9 0}$ children were treated conventionally with spectacles, occlusion, and operation when necessary.

Thirty six of them had been entered into a randomised trial of treatment from age 1 year, of whom 16 were drawn for treatment. All 36 have been included because treatment from 1 year did not obviously alter the visual outcome. ${ }^{6}$

Visual acuity was measured with the linear Sheridan-Gardiner or Snellen tests, and it is the last known acuity for the worse eye which is reported.

\section{Results}

The last known acuities are recorded in two tables. In Table I the ages of onset are shown and in Table II the duration of squint before presentation. In each table, the children are divided into two groups: those who had 3.5 or more D meridional hypermetropia at age 1 year and those who had less than $3.5 \mathrm{D}$ meridional hypermetropia at 1 year.

The findings recorded in each table were subjected to three-way contingency analysis. No evidence was found to suggest that the age of onset or duration of the squint between onset and presentation significantly determined the visual outcome. The only significant predictor of a poor 
TABLE III Meridional hypermetropia and final acuity

\begin{tabular}{lll}
\hline & \multicolumn{2}{l}{ Last known visual acuity } \\
\cline { 2 - 3 } Meridional hypermetropia at age 1 year & $6 / 18$ or better & $6 / 24$ or less \\
\hline 3.5 D or more & 22 & 12 \\
<3.5 D & 52 & 4 \\
\hline
\end{tabular}

$\chi^{2}=9 \cdot 625, \mathrm{p}<0 \cdot 01$.

final acuity of $6 / 24$ or less was meridional hypermetropia (Table III).

\section{Discussion}

Worth' believed that early onset of squint or delay in starting treatment was associated with lower acuity retained by the squinting eye after treatment. Costenbader $e t a l^{2}$ reported observations on 316 children, but their conclusions referred only to the incidence of amblyopia (20/ 40 or less) associated with squint. We were interested in the severity of amblyopia. In these 90 children severe amblyopia (6/24 or less) remaining after treatment was not related to the reported age of onset of the squint, nor to any delay in starting treatment. Three possible factors could contribute to the difference between our findings and those of Worth.' Firstly, $50 \%$ of his children had $6 / 36$ visual acuity or less after treatment, whereas only $15 \%$ of ours fared as badly. Secondly, since 1981 we have watched many children in whom we expected squint to appear, but nevertheless we still found it quite difficult to date the exact time of onset of the squint. The recorded age of onset of squint for many of the children in this sample, particularly those who were abnormally hypermetropic in infancy, may not, therefore, be strictly accurate. Thirdly, if we had studied larger numbers of children, it is possible that significant associations between the age of onset or duration of squint and relatively severe amblyopia might have emerged.

However, our principal conclusion is that in this limited number of children abnormal hypermetropia at the age of 1 year was the principal factor associated with severe residual amblyopia even after full treatment. The age of onset of squint and delay in starting treatment do not appear to be of as much importance as was previously thought.

We are greatly indebted to Dr S M Gore of the MRC Biostatistics Unit at thank Mrs L Neale for many hours of secretarial work.

1 Worth C. Squint: its causes, pathology and treatment. London: Bale and Danielsson, 1903: 76-7.

2 Costenbader F, Bair D, McPhail A. Vision in strabismus. Arch Ophthalmol 1948; 40:438-53.

3 Ingram RM, Walker C, Wilson JM, Arnold PE, Dally S. Prediction of amblyopia and squint by means of refraction at Prediction of amblyopia and squint by means
age 1 year. Brf Ophthalmol 1986; 70: 12-5.

4 Ingram RM. Refraction of 1 -year-old children after atropine cycloplegia. Brf Ophthalmol 1979; 63: 343-7.

5 Ingram RM, Barr A. Refraction of 1-year-old children after cycloplegia with $1 \%$ cyclopentolate: comparison with findings after atropinisation. Br f Ophthalmol 1979; 63: 34852 .

6 Ingram RM, Walker C, Wilson JM, Arnold PE, Lucas J, Dally S. A first attempt to prevent amblyopia and squint by spectacle correction of abnormal reft
Brf Ophthalmol 1985; 69: 851-3. 